\title{
PERANAN PEMBANGUNAN MINAT KEWIRAUSAHAAN PADA SISWA PAUD DALAM MENYAMBUT MEA DENGAN MODEL MENJUAL KARYA SENDIRI
}

\author{
Fajar Kurniadi \\ Dosen Program Studi Pendidikan Ekonomi Universitas Indraprasta PGRI \\ E-mail: fajaruntukindonesia@gmail.com
}

\begin{abstract}
Abstrak : Indonesia merupakan salah satu Negara Asean dengan luas wilayah terbesar dan Negara berpenduduk terbanyak. Dengan melimpahnya SDA dan SDM Indonesia, maka seharusnya Indonesia memiliki modal yang sempurna untuk menghadapi MEA 2015. MEA merupakan saluran yang tepat bagi para pelaku ekonomi untuk memperluas usaha. Penulis melihat sebuah peluang bagi seluruh SDM Indonesia untuk terlibat didalamnya bahkan dari usia dini. Anak usia dini dapat dilibatkan dengan membangun minat kewirausahaan melalui metode menjual hasil karya peserta didik. Fakta di lapangan membuktikan sejumlah PAUD membuat bazar di akhir proses pendidikan. Hal ini mengindikasikan bahwa sejak dini anak sudah dapat ditanamkan minat kewirausahaan. Untuk mengetahui peranan pembangunan minat kewirausahaan pada anak usia dini maka penulis menggunakan data sekunder yang diperoleh melalui kajian pustaka dengan mengumpulkan sejumlah informasi dan data yang nanti akan diolah menjadi simpulan.
\end{abstract}

\section{Kata kunci: pembangunan minat, wirausaha, PAUD, MEA}

\section{PENDAHULUAN}

Secara geografis, Indonesia diapit oleh dua samudra dan dua benua. Samudra Pasifik dan Samudra Hindia melintang dari utara ke selatan, benua Asia dan benua Australia yang menjadi batas Indonesia. Letak geografis yang memanjakan ini membuat Indonesia menjadi negara yang potensial bagi perkemabangan ekonomi. Perekonomian dapat dilakukan dari berbagai sarana transportasi, mulai dari laut hingga udara. Kelautan Indonesia pun ditunjang dengan hasilnya yang melimpah sehingga dapat menjadi sumber penjualan bagi pemasukan Indonesia. Tidak hanya di sektor kelautan yang berpotensi mendongkrak sistem perekonomian Indonesia. Sektor kehutanan, perkebuanan, pertambangan, dan pertanian juga sangat berpengaruh bagi perkembangan ekonomi Indonesia.

Selain dlimpahi sumber daya alam yang banyak, Indonesia pun patut berbangga karena sumber daya manusia Indonesia pun melimpah. Hingga tahun 2010, sumber daya manusia Indonesia mencapai 237.641.326 jiwa (www.bps.go.id). Hal ini menjadi potensi tersendiri bagi Indonesia untuk sebaikbaiknya mengolah sumber daya alam yang melimpah. Potensi dari kedua sumber daya ini sebenarnya merupakan bekal sempurna bagi Indonesia untuk menguasai perekonomiannya sendiri.

Selain letak dan sumber daya yang memanjakan, Indonesia juga dimanjakan secara ekonomi dengan menjadi anggota ASEAN. Kerja sama ekonomi ASEAN 
ditujukan untuk menghilangkan hambatan-hambatan ekonomi dengan cara saling membuka perekonomian negara-negara anggota dalam menciptakan kesatuan ekonomi kawasan. Kerja sama ekonomi mencakup berbagai kerja sama di sektor perindustrian, perdagangan, dan pembentukan Kawasan Perdagangan Bebas di ASEAN. Indonesia tengah bersiap menghadapi Masyarakat Ekonomi ASEAN (MEA) 2015. Dampak terciptanya MEA adalah pasar bebas di bidang permodalan, barang dan jasa, serta tenaga kerja.

Pembentukan Masyarakat Ekonomi ASEAN (MEA) berawal dari kesepakatan para pemimpin ASEAN dalam Konferensi Tingkat Tinggi (KTT) pada Desember 1997 di Kuala Lumpur, Malaysia. Kesepakatan ini bertujuan meningkatkan daya saing ASEAN serta bisa menyaingi Tiongkok dan India untuk menarik investasi asing. Modal asing dibutuhkan untuk meningkatkan lapangan pekerjaan dan kesejahteraan warga ASEAN. Pada KTT selanjutnya yang berlangsung di Bali Oktober 2003, petinggi ASEAN mendeklarasikan bahwa pembentukan MEA pada tahun 2015. MEA merupakan saluran yang tepat bagi pelaku ekonomi untuk memperluas usaha mereka. Melihat persaingan yang akan terjadi, pelaku ekonomi harus memiliki modal berupa pendidikan kewirausahaan. Kemajuan ekonomi akan dapat dicapai jika ada semangat kewirausahaan, yang kuat dari warganya. Upaya yang diarahkan untuk mencapai semangat kewirausahaan baru sebatas pendidikan kewirausahaan ditingkat perguruan tinggi. Alangkah lebih baiknya jika pendidikan kewirausahaan ini ditanamkan sejak dini agar lebih melekat dan menjadi landasan serta mampu diamalkan dalam keseharian anak hingga ia dewasa. Hal ini sesuai dengan peribahasa belajar di waktu kecil bak mengukir di atas batu dan belajar di waktu dewasa bak melukis di atas air. Pendidikan kewirausahaan pada usia dini mutlak diperlukan untuk menjawab tantangan perekonomian ke depan.

Dalam kaitannya dengan pendidikan dimulai dari usia dini, pendidikan anak usia dini memiliki peranan yang sangat menentukan. Pada usia ini berbagai pertumbuhan dan perkembangan mulai dan sedang berlangsung, seperti perkembangan fisiologis, bahasa, motorik, kognitif. Perkembangan ini akan menjadi dasar bagi perkembangan anak selanjutnya. Oleh karena itu, maka perkembangan pada masa awal ini akan menjadi penentu bagi perkembangan selanjutnya begitu pula dengan keberhasilan pada masa awal akan menentukan keberhasilan bagi perkembangan selanjutnya. Perkembangan anak usia dini melaju pesat, ditandai dengan terus bertambahnya jumlah lembaga Pendidikan Anak Usia Dini (PAUD). Taman Kanak-kanak (TK), Raudatul Atfal (RA), Kelompok Bermain (KB), Taman Pendidikan AlQuran (TPA), dan PAUD sejenis lainnya banyak bermunculan. Masyarakat harus sadari bahwa PAUD memegang peranan penting dalam kemajuan bangsa Indonesia, termasuk di bidang ekonomi dengan momentum MEA ini.

Hal yang harus dilakukan untuk mendidik anak usia dini dalam berwirausaha adalah pembangunan minatnya. Anak usia dini dapat dilibatkan dalam pembangunan minat kewirausahaan dengan cara yang sederhana dan menyenangkan, yakni dengan menjual hasil karya mereka berupa makanan atau cinderamata. Tidak perlu dalam lingkup jauh atau luas, cukup sekitar lingkungan mereka belajar seperti di arena bermain, play group, Taman Kanak-Kanak, Taman Pendidikan Al-Quran, atau di tempat yang menyenangkan lainnya. Ini sesuai fakta yang terjadi bahwa banyak tempat dengan basis pendidikan anak usia dini 
menggelar bazar untuk hasil karya siswanya. Kegiatan ini berguna anak mampu mengenal lingkungannya, menghargai keragaman sosial, menguasai bahasa, mengelola gerakan motorik, berpikir logis, memberikan alasan, dan memecahkan masalah. Semua hal ini diperlukan untuk menjawab tantangan ekonomi ke depan.

Melihat kenyataan yang terjadi, sangat penting rasanya untuk mengetahui peranan pembangunan minat kewirausahaan pada siswa PAUD dalam menyambut MEA dengan model menjual karya sendiri. Apa-apa saja yang akan disiapkan dan dilakukan dalam menyambut MEA dikaitkan dengan PAUD.

\section{KAJIAN PUSTAKA \\ Hakikat Minat}

Minat menurut Kamus Besar Bahasa Indonesia (2008) adalah kecendrungan hati yang tinggi terhadap sesuatu. Sedangkan menurut Hilgard dalam Slameto (2003) minat adalah kecenderungan yang tetap untuk memperhatikan dan mengenang beberapa kegiatan. Kegiatan yang diminati seseorang, diperhatikan terus menerus yang disertai dengan rasa senang. Purwanto (1998) mengartikan minat sebagai resultan dari proses eksplorasi dan manipulasi yang dilakukan oleh seorang terhadap sesuatu. Dari pengalaman eksplorasi dan manipulasi terhadap sesuatu, seseorang akan berkembang ke arah berminat atau tidak berminat kepada sesuatu itu. Sesuatu yang menarik minat itu tidak hanya menyenangkan atau dapat mendatangkan kepuasan baginya, tetapi juga yang menakutkannya.

Sementara Kartini Kartono (1980) mengartikan minat sebagai moment dari kecenderungan-kecenderungan yang terarah secara intensif kepada satu objek yang dianggap penting. Pada minat selalu terdapat elemen-elemen afektif (perasaan, emosional) yang kuat.

Slameto (2003) mengartikan minat sebagai suatu rasa lebih suka dan rasa keterikatan pada suatu hal atau aktivitas, tanpa ada yang menyuruh. Minat pada dasarnya adalah penerimaan akan suatu hubungan antara dirinya dengan sesuatu dengan diluar dirinya. Semakin kuat atau dekat hubungan tersebut, maka semakin besar minat. Suatu minat dapat ditunjukkan dalam suatu pernyataan siswa lebih menyukai suatu hal dibanding hal yang lain, dan dapat diwujudkan dengan partisipasi dalam cenderung memberi memberi perhatian yang lebih besar terhadap suatu subyek tersebut. Lebih lanjut Ancok (1998) mengatakan bahwa minat menampilkan sikap dari sebuah pribadi, yang muncul langsung dari "aku"nya seseorang. Pada minat ini terdapat unsur pengenalan (kognitif), emosi-emosi atau unsur efektif, dan kemauan atau unsur volutif/kognitif untuk mencapai suatu objek. Minat dapat dibangkitkan dengan bantuan motivasi-motivasi dan emosiemosi. Dengan minat tergugah dan terbimbing, seseorang menjadi terus aktif dan sibuk, sehingga dapat menimbulkan perasaan "berarti" dan "bahagia" meminati sesuatu. Dengan demikian minat dapat diartikan sebagai sebuah konsekuensi logis dari aktivitas eksplorasi dan manipulasi terhadap suatu yang dilakukan oleh seseorang. Minat memuat elemen-elemen afeksi seperti emosi atau perasaan atau hal itu dapat mengalami fluktuasi. Agar menjadi terus tumbuh dan berkembang, minat tersebut harus dikontribusi oleh motivasi-motivasi dan emosi. Dengan minat yang terbimbing dan tergugah, seseorang menjadi aktif. 


\section{Hakikat Wirausaha}

Istilah kewirausahaan (enterpreuneur) pertama kali diperkenalkan pada abad ke-18 oleh ekonom Prancis, Richard Cantilon. Menurutnya, enterpreuneur adalah agent who buys means of production at certain prices in order to combine them. Secara etimologi, wirausaha berasal dari bahasa Sansekerta, terdiri atas dua suku kata: "wira", dan "usaha". Kata "wira" berarti pejuang, pahlawan, manusia unggul, teladan, berbudi luhur, gagah berani dan berwatak agung; dan kata "usaha" berarti perbuatan amal, bekerja, dan berbuat sesuatu. Istilah wirasusaha kadang disamakan dengan wiraswasta, hal ini sesuai dengan petunjuk dari Kamus Besar Bahasa Indonesia (2008) merujuk kata wiraswasta untuk kata wirausaha dengan menulis wisaswasta adalah orang yang pandai atau berbakat mengenali produk baru, menentukan cara produksi baru, memasarkannya, serta mengatur permodalan operasinya. Hal ini mengindikasikan kedua istilah tersebut hampir sama. Secara etimologis, kata wiraswasta (Dikti, 2013) berasal dari bahasa Sansekerta yang terdiri atas 3 kata, Wira berarti manusia unggul, teladan, tangguh, berbudi luhur, berjiwa besar, berani, pahlawan, pionir, pendekar/pejuang kemajuan, memiliki keagungan watak. "Swa" berarti sendiri, dan "Sta" berarti berdiri.

Kewirausahaan berdasarkan sumber di atas berorientasi kepada subjeknya. Manusia tangguh yang mampu melihat peluang untuk dijadikan usaha memajukan dirinya sendiri dan tanpa bergantung kepada orang lain. Berbeda pandangan dengan Instruksi Presiden Republik Indonesia Nomor 4 Tahun 1995 tentang Gerakan Nasional Memasyarakatkan dan Membudayakan Kewirausahaan mengungkapkan bahwa kewirausahaan adalah semangat, sikap, perilaku dan kemampuan seseorang dalam menangani usaha dan atau kegiatan yang mengarah pada upaya mencari, menciptakan, menerapkan cara kerja, teknologi dan produk baru dengan meningkatkan efisiensi dalam rangka memberikan pelayanan yang lebih baik dan atau memperoleh keuntungan yang lebih besar. Dalam hal ini, kewirausahaan dijadikan sebagai peletup semangat untuk menangani usaha dan meningkatkat efisiensi, berarti subjeknya sudah mempunyai usaha dan berwirausaha untuk meningkatkan usahanya agar lebih maju dan efisien.

Drucker dalam Kasmir (2011) mengatakan "Kewirausahaan merupakan kemampuan dalam menciptakan sesuatu yang baru dan berbeda." Drucker melihat kewirausahaan lebih luas dengan tidak menyebut batasan dalam bidang apa saja yang termasuk kewirausahaan, penciptaan sesuatu yang baru adalah hal paling penting untuk berwirausaha.

\section{Hakikat PAUD}

Sebelum membahas PAUD, ada baiknya kita mengenal dan mengetahui hakikat dari anak usia dini. Sudjiono (2009) mengemukakan anak usia dini merupakan sosok individu yang sedang menjalani suatu proses perkembangan yang pesat dan fundamental bagi kehidupan selanjutnya. Anak usia dini berada pada rentang 0-8 tahun. Pada usia ini, anak sedang mengembangkan berbagai kemampuannya terutama di bidang kesadaran personal, perkembangan emosi, membangun sosialisasi, pengembangan komunikasi, pengembangan kognitif, dan pengembangan kemampuan motorik. Tahapan usia dini ini merupakan tahapan emas dalam perkembangan belajar anak. 
Hal ini juga disampaikan Santoso (2004) dengan menyatakan pendidikan yang ideal dan baik semestinya dilakukan sejak anak lahir sampai remaja dengan dikembalikan kepada alam atau pendekatan secara alamiah. Jika anak dapat bersatu dengan alam, ia akan bahagia dan rasa ingin tahunya akan tumbuh. Dari rasa ingin tahunya inilah anak dapat belajar dan mengembangkan kemampuannya berdasarkan jenjang usianya. Ditambah lagi akan membuat anak lebih peka terhadap lingkungan sekitar untuk meraih pendidikan.

Berdasarkan Undang Undang Nomor 20 tahun 2003 tentang Sistem Pendidikan Nasional pada pasal 28 ayat 1 berbunyi "Pendidikan anak usia dini diselenggarakan bagi anak sejak lahir sampai dengan enam tahun dan bukan merupakan prasyarat untuk mengikuti pendidikan dasar. "Pendidikannya pun dilakukan dengan cara memberikan rangsangan untuk membantu perkembangan jasmani dan rohani agar anak lebih siap dalam memasuki pendidikan selanjutnya.

Pendidikan anak pada usia dini pada dasarnya meliputi tindakan yang dilakukan oleh orang tua atau pendidik dalam proses pengasuhan pada anak dengan menciptakan suasana dan lingkungan di mana anak dapat mengeksplorasi pengalaman yang memberikan kesempatan kepadanya untuk mengetahui dan memahami pengalaman belajar yang diperolehnya dari lingkungan, melalui cara mengamati, meniru, dan bereskperimen yang dilakukan secara berkala dan terus menerus dengan melibatkan potensi dan kecerdasan anak.

Diharapkan dengan kehadiran PAUD, anak usia dini diberikan wadah untuk mengelola potensinya menjadi prestasi. Hal ini sesuai dengan Latif, dkk (2013) mengemukakan "PAUD diarahkan untuk memberikan fasilitas tumbuh kembang anak secara sehat dan optimal sesuai dengan nilai, norma, dan harapan masyarakat." Nilai, norma, dan harapan masyarakat diawali dari tingkat pendidikan anak usia dini. Maka, tentunya pendidikan anak di usia dini harus menjadi prioritas bagi semua kalangan, termasuk pelaku ekonomi. Perekonomian di masa depan berada di tangan anak usia dini masa ini. Maka pembekalan dari sudut pandang ekonomi dirasa sangat penting untuk menunjang keberhasilan perekonomian nasional mendatang. Tentunya pemberian materi perekonomian khususnya kewirausahaan dalam tingkat anak usia dini berbeda dengan tingkatan lainnya. Metode dan modelnya harus disesuaikan dengan usianya.

Model pembelajaran dalam PAUD dibagi ke dalam 3 bagian. Latif (2013) mengungkapkan pendekatan yang pertama adalah pendekatan model pematangan yakni menganggap anak memiliki blueprint pola tingkah laku sendiri sehingga perubahan tingkah lakunya terjadi karena perubahan psikologis dan lingkungan; kedua, model aliran tingkah laku lingkungan yakni model yang menganggap anak sebagai batu tulis yang kosong sehingga perubahan tingkah laku terjadi sebagai hasil penguatan suatu peristiwa yang terencana dan tidak terencana; ketiga, model interaksi yakni model yang beranggapan anak merupakan hasil perpaduan antara minat dan pengaruh lingkungan. Perkembangan model interaksi akan terjadi bila anak melakukan pengorganisasian diri yang dicapai pada tahap optimal oleh peristiwa yang dieksperimentasikan. Model inilah yang biasanya digunakan dalam kurikulum PAUD.

Kebanyakan dari kurikulum PAUD itu adalah bermain. Bermain menurut KBBI (2008) merupakan "melakukan sesuatu untuk bersenang-senang." Hal ini serupa dengan Masnipal (2013) "Bermain adalah menyenangkan karena para pemain memperoleh pengalaman menyenangkan.”Bermain di lingkungan PAUD 
harus memperhatikan perkembangan perilaku. Perkembangan perilaku meliputi 4 yakni interpersonal, intrapersonal, spiritual, dan naturalistik. Perkembangan interpersonal berhubungan dengan rasa sayang pada anggota keluarga, rasa empati, dan sabar. Perkembangan intrapersonal meliputi menunjukkan rasa percaya diri, dapat melakukan pekerjaan sendiri, dapat mengenalkan dan mematuhi aturan, dan berdisiplin dalam kehidupan sehari-hari. Perkembangan spiritual meliputi kegiatan keagamaan seperti membaca doa, bersyukur, dan lainnya. Perkembangan naturalistik meliputi dapat mengenal perilaku sekitar dengan pancaindera. Dalam hal pembangunan minat kewirausahaan, perkembangan yang diharapkan adalah dari perkembangan intrapersonal. Untuk merangsang perkembangan itu, dapat dilakukan berbagai permainan diantaranya adalah dengan kreasi terhadap objek. Objek yang dimaksud dapat berupa makanan atau cinderamata, hasil dari kreasi terserbut dapat ditunjukkan atau dijual ke lingkungan sekitar PAUD agar membentuk minatnya terhadap lingkungan dan berwirausaha. Langkah kecil yang dapat mengubah rasa.

Hasil dari pendidikan di usia dini baru akan dirasakan saat siswa PAUD beranjak dewasa, namun pembekalan yang mendalam dan membekas akan menjadi modal yang berharga dalam mengarungi kehidupan. Terlebih tantangan di dunia perekonomian yang tidak dapat dianggap remeh, salah satunya adalah MEA.

\section{Hakikat MEA}

Masyarakat Ekonomi ASEAN (MEA) adalah realisasi tujuan akhir dari integrasi ekonomi yang dianut dalam Visi 2020, yang didasarkan pada konvergensi kepentingan negara-negara anggota ASEAN untuk memperdalam dan memperluas integrasi ekonomi melalui inisiatif yang ada dan baru dengan batas waktu yang jelas. dalam mendirikan Masyarakat Ekonomi ASEAN (MEA), ASEAN harus bertindak sesuai dengan prinsip-prinsip terbuka, berorientasi ke luar, inklusif, dan berorientasi pasar ekonomi yang konsisten dengan aturan multilateral serta kepatuhan terhadap sistem untuk kepatuhan dan pelaksanaan komitmen ekonomi yang efektif berbasis aturan.

Pada saat yang sama, Masyarakat Ekonomi ASEAN (MEA) akan mengatasi kesenjangan pembangunan dan mempercepat integrasi terhadap Negara Kamboja, Laos, Myanmar dan Vietnam melalui Initiative for ASEAN Integration dan inisiatif regional lainnya.

Bentuk Kerjasamanya adalah :

1. Pengembangan sumber daya manusia dan peningkatan kapasitas;

2. Pengakuan kualifikasi profesional;

3. Konsultasi lebih dekat pada kebijakan makro ekonomi dan keuangan;

4. Langkah-langkah pembiayaan perdagangan;

5. Meningkatkan infrastruktur

6. Pengembangan transaksi elektronik melalui e-ASEAN;

7. Mengintegrasikan industri di seluruh wilayah untuk mempromosikan sumber daerah;

8. Meningkatkan keterlibatan sektor swasta untuk membangun Masyarakat Ekonomi ASEAN (MEA). 


\section{PEMBAHASAN}

\section{Peranan Pembangunan Minat Kewirausahaan pada Siswa PAUD dalam Menyambut MEA dengan Model Menjual Karya Sendiri}

PAUD merupakan pendidikan paling kedua setelah pendidikan keluarga. Pendidikan untuk anak usia dini memberikan dampak yang sangat banyak karena merupakan peletakan dasar bagi kemampuan dan keberhasilan anak di masa depan.

Berdasarkan beberapa temuan, peletakan dasar ini meliputi beberapa aspek yakni agama, susila, kasih sayang, kesenangan, dan ekonomi. Aspek ekonomi ini dilakukan di akhir pembelajaran berupa praktik membuat keterampilan dan berusaha untuk dijual. Penjualan produk mereka pun tidak jauh cakupannya, biasanya dilakukan di lingkungan sekolah mereka atau lingkungan tempat tinggal mereka. Targetnya pun hanya keluarga atau teman-teman mereka di rumah. Hasilnya bervariasi, dapat dilihat dalam tabel berikut:

Tabel 1. Rincian data sekunder beberapa TK berkaitan dengan minat

\begin{tabular}{|c|c|c|c|c|c|}
\hline TK Minat & Pasif & Aktif & Tertarik & Antusias & Jumlah \\
\hline A & 2 & 4 & 8 & 9 & 23 \\
\hline B & 2 & 6 & 7 & 11 & 26 \\
\hline C & 0 & 1 & 2 & 16 & 19 \\
\hline
\end{tabular}

Tabel diambil dari data sekunder beberapa TK di daerah Depok secara acak. Dari tabel di atas, dapat dinyatakan bahwa banyak siswa PAUD yang dinyatakan antusias. Hal ini dinilai sangat baik dalam rangka pembentukan minat siswa PAUD dalam berwirausaha. Tajuk yang dibawa dalam pembentukan minat ini adalah bermain terhadap objek kue dan menjualnya. TK A yang mempunyai 23 siswa memiliki siswa yang beragam. Dua siswa TK A dinyatakan pasif karena saat menjual hasil karyanya, mereka hanya diam dan terpaku melihat temantemannya. Diantara perilaku siswa TK A, ada sembilan siswa yang antusias dengan berperilaku sangat responsif terhadap perintah guru dan sangat bersemangat dalam menasarkan produknya. Bahasa yang digunakan pun dapat mengalihkan beberapa orang tua untuk tertarik dengan produk mereka.

Hasil yang hampir sama diperoleh di TK B. Kali ini persebaran antara siswa yang aktif dan tertarik memiliki sedikit perbedaan. Siswa aktif di TK B sebanyak 6 orang, dinyatakan demikian karena keenamnya hanya mengikuti dan tidak berinisitif untuk berkreasi membentuk produk mereka sendiri. Mereka hanya mengadopsi atau mengikuti kegiatan temannya. Sementara itu, ada tujuh siswa yang tertarik dengan kegiatan ini, dibuktikan dengan aktivitas mereka begitu bersemangat dalam membuat dan memasarkan produk mereka, hanya saja pemasarannya hanya untuk orang tua mereka. Mereka masih ragu untuk memasarkan produknya ke orang lain.

Hasil paling baik diraih di TK C, rata-rata siswa menunjukkan antusiasnya dalam melakukan perintah guru dengan membuat produk semenarik mungkin dan memasarkannya dengan menarik. Pemasaran mereka lakukan menggunakan bahasa dan gaya yang unik khas anak-anak. Main "jual-jualan" merupakan hal yang menyenangkan untuk mereka. Orang tua mereka pun sangat senang 
mendapati anaknya antusias dalam membuat dan memasarkan produk dengan tingkah lucu dan menggemaskan.

Berdasarkan kegiatan di beberapa TK di atas, pembangunan minat kewirausahaan siswa PAUD berlangsung lancar dan diharapkan berdampak positif dengan pandai melihat peluang, memanfaatkan potensi, dan mampu memasarkan serta dapat bersaing dalam kehidupan ekonomi mereka sendiri. Akan sangat menyenangkan jika mereka mampu berwirausaha dan membawa Indonesia manjadi tuan rumah di negaranya sendiri. Bukan menjadi penonton melainkan menjadi pemain dalam persaingan ekonomi yang semakin ketat dan penuh tantangan.

\section{SIMPULAN}

Berdasarkan hasil yang ditemui, dapat disimpulkan:

1. Pembangunan minat kewirausahaan dinilai penting demi terciptanya iklim ekonomi yang kompetitif,

2. Pembangunan minat kewirausahaan sebaiknya dilakukan di lingkungan pendidikan dini sebagai peletakkan landasan ekonomi yang kuat,

3. Pembangunan minat kewirausahaan di tingkat pendidikan dini dapat dilakukan dengan memasarkan hasil karyanya sendiri agar tercipta rasa senang dan bangga bagi pembuatnya.

\section{DAFTAR PUSTAKA}

\section{Buku:}

Ditjen Dikti. 2013. Kewirausahaan: Modul Pembelajaran. Jakarta: Dirjen Pembelajaran dan Kemahasiswaan.

Kasmir. 2011. Kewirausahaan. Jakarta: PT Raja Grafindo Persada.

Kartono, Kartini. 1980.Teori Kepribadian. Bandung : Alumni.

Latif, Mukhtar. Dkk. 2013. Orientasi Baru Pendidikan Anak Usia Dini: Teori dan Praktik. Jakarta: Kencana Prenada Media Group.

Maspinal. 2013. Siap Menjadi Guru dan Pengelola PAUD Profesional. Jakarta: PT Elex Media Komputindo.

Purwanto, M. Ngalim. 1995.Ilmu Pendidikan dan Praktek. Jakarta : PT. Remaja Rosdakarya., Bandung.

Pusat Bahasa. 2008. Kamus Besar Bahasa Indonesia ed ke-4. Jakarta: PT Gramedia Pustaka Utama.

Slameto. 2003.Belajar dan Faktor yang Mempengaruhinya. Jakarta: Rineka Cipta

Sujiono, Yuliani Nuraini dan Bambang Sujiono. 2010. Bermain Kreatif Berbasis Kecerdasan Jamak. Jakarta: PT Indeks. 
Research and Development Journal Of Education

Vol. 1 No. 2 April 2015

Santoso, Soegeng. 2004. Pendidikan Anak Usia Dini. Jakarta: Penerbit Citra Pendidikan.

Sujiono, Yuliani Nurani. 2009. Konsep Dasar Pendidikan Anak Usia Dini. Jakarta: PT Indeks

\section{Internet:}

Badan Pusat Statistik. Penduduk Indonesia menurut Provinsi 1971, 1980, 1990, 1995, 2000 dan 2010. (Februari 2013) http://www.bps.go.id/tab_sub/view.php?tabel=1\&id_subyek=12 diunduh pada 7 Februari 2015.

Tanpa Nama. Pengertian MEA. (November 2013) http://seputarpengertian.blogspot.com /2014/08/Pengertian-karakteristikmasyarakat-ekonomi-asean.html diunduh pada 16 Februari 2015. 